\title{
Biological effects of a novel intestinal peptide - inhibiting enterocytogenin on cultured 3T3 mouse fibroblasts and L5178Y mouse lymphoma cells
}

\author{
Borislav B. Trifonov ${ }^{a}$, George K. Rousev ${ }^{a}$, Ognjan Argirov ${ }^{b}$, Marian M. Draganov ${ }^{b}$ and \\ Emmanuel S. Kamberov ${ }^{\mathrm{c}, *}$ \\ "Department of Physiology, Medical University, 4000 Plovdiv (Bulgaria), 'Departments of Organic Chemistry and Cell Biology, Paisji \\ Hilendarski University of Plovdiv, 4000 Plovdiv (Bulgaria) and ${ }^{\circ}$ Department of Biological Chemistry, University of Michigan Medical School. \\ Medical Science I, 1301 Catherine Rd., Ann Arbor, MI 48109-0606 (USA)
}

(Received 25 October 1993; revised version received 10 January 1994; accepted 21 January 1994)

Key words: Growth inhibition; Cell culture; Intestinal peptide

\section{Summary}

The effects of a new intestinal peptide, inhibiting enterocytogenin (IEG) derived from pig intestinal mucosa were studied in vitro on 3T3 mouse fibroblasts and L5178Y mouse lymphoma cell line. IEG caused considerable growth inhibition together with specific morphological changes, necrotic effects as well as formation of monolayers at the highest concentration applied $(1000 \mu \mathrm{g} / \mathrm{ml})$. A biologically active fraction (IEG-BAF) derived by further purification of IEG by gel-filtration, proved to possess most of the described activity. The concentrations of IEG and IEG-BAF inhibiting the growth of L5178Y lymphoma cells by $50 \%$ (IC 50 values) were calculated to be $759 \mu \mathrm{g} / \mathrm{ml}$ and $192 \mu \mathrm{g} / \mathrm{ml}$, respectively. IEG-BAF has a molecular mass of $4450 \pm 180 \mathrm{Da}$ and is most probably a peptidylnucleotidate as revealed by spectral analysis.

\section{Introduction}

As a result of intensive experimental research during the last decade a number of biologically active

* Coresponding author. peptides have been found in mammalian intestine, which proved to affect the proliferation of different cell types [1-6]. However, very little is known about their chemical composition, molecular structure and biological functions. Even the existence of some of these intestinal factors is still hypothetical and the subject of argument [1]. Which of the isolated 
substances are real regulatory peptides and wether or not they can be included in the family of the gastrointestinal hormones is a question of future more detailed studies.

In 1989 Skraastad and Reichelt [2] isolated and purified an endogeneous inhibitor from mouse small intestine which is an oligopeptide consisted of three amino acids -pGlu-His-Gly-OH and proved to inhibit the mitosis of colon epithelial cells. It also caused a significant decrease of the incorporation of $\left[{ }^{3} \mathrm{H}\right.$ ] thymidine in HT-29 human carcinoma cells and its activity was specifically blocked by insulin. In a separate study [3] the same authors reported an inhibition of the increased colonic epithelial cells proliferation in mice, induced by cholic acid upon i.p. administration of the oligopeptide and also found a dietary calcium dependance of its inhibitory effect.

In our previous reports [4,5] we have described the isolation of several endogeneous bioactive substances from canine and porcine intestinal cells from duodenum, and the proximal and distal jejunum and ileum. These compounds were divided in two major groups, inhibiting or stimulating, based on their differential long-termt effects on the incorporation of $\left[{ }^{3} \mathrm{H}\right]$ thymidine and $\left[{ }^{14} \mathrm{C}\right]$ leucine in the intestinal mucosa and muscles after i.p. injection in mice. Their chemical nature and molecular mass ranged from large proteins $(300 \mathrm{kDa})$ to small peptides $(550-$ $5000 \mathrm{Da}$ ), containing or not nucleosides or chromophor groups in their structure [5]. Two peptides possesing strong morphogenic effects were further purified from the mucosa of pig small intestine, referred to as stimulating enterocytogenin (SEG) and inhibiting enterocytogenin (IEG), respectively, and a method for their industrial scale purification was developed (patent BG \# 49927A/92D [6]). SEG which is known under the pharmaceutical trade mark Enterogenin $^{\mathrm{R}}$ is an adenosyl-hexapeptide complex with a molecular mass of $1400 \mathrm{Da}$. Its amino acid sequence differs from that of the known intestinal regulatory peptides [4-6]. SEG causes generalized long-term effects on the cell metabolism, stimulates the biosynthetic pathways and reduces the prolifera- tion cycle of the physiologically regenerating intestinal mucosa cells. It also increases the number and the length of the intestinal microvilli and improves the resorption via the intestinal mucosa. In nonproliferating cells SEG stimulates the synthesis of specific proteins: miosin in skeletal muscles, detoxicating enzymes in liver, immunogenic proteins in spleen, digestive enzymes in the gastrointestinal tract [6]. SEG also causes depolarization of isolated smooth muscle preparations from rat gastrointestinal tract, stimulates the $\mathrm{Ca}^{2+}$ influx and increases the contractility. These effects can be specifically blocked by haloperidol [7].

Our preliminary characterization of IEG revealed that it is a product of the degradative metabolism in the immature cells of the small intestine [5]. It acts as a general inhibitor of the enterocytic proliferation and differentiation. IEG also stimulates in vitro the contractility of smooth muscle preparations from the gastrointestinal tract of rat and guinea-pig. These effects of IEG on guinea-pig smooth muscle cells are greately abolished by $\mathrm{H} 2$ histamine blockers [8].

We describe here the effects of crude as well as further purified by gel-filtration IEG on cultured 3T3 mouse fibroblasts and L5178Y mouse lymphoma cell line and we show that IEG causes a considerable growth inhibition and typical morphological changes of these cells.

\section{Materials and Methods}

\section{Isolation of IEG}

IEG was obtained from pig intestinal mucosa under industrial-scale conditions as described [6]. The lyophilized material was dissolved in water or in phosphate-buffered saline and sterilized by microfiltration through $0.45 \mu \mathrm{m}$ Millipore membrane filters prior to addition to the cell cultures.

\section{Gel filtration of IEG}

The chromatography was carried out on Sephadex G-25 (medium grade) at a flow rate of $19 \mathrm{ml} / \mathrm{h} / \mathrm{cm}^{2}$, using FPLC (Pharmacia) equipment. Columns of 
dimensions $1 \times 47 \mathrm{~cm}$ or $2 \times 40 \mathrm{~cm}$ (I.D.) were used for analytical or for preparative scale purification, respectively. The elution was carried out with 0.035 $\mathrm{M}$ potassium phosphate buffer ( $\mathrm{pH}$ 6.8) or with redistilled deionazed water and the eluate was continuously monitored at $280 \mathrm{~nm}$. The protein content of the collected fractions was determined by the methods of Lowry [9] or Warburg and Crystian [10], respectively. Fractions were sterilized as described above and tested for biological activity. The peak of activity causing the highest percentage of growth inhibition of the tested L5178Y mouse lymphoma cells was referred to as the inhibiting enterocytogeninbiologically active fraction (IEG-BAF). Spectral analysis of the fractions in the visible and UV range was carried out on Perkin-Elmer model Lambda-15 spectrophotometer.

\section{HPLC of the purified IEG-BAF}

Analysis of the purified IEG-BAF was done on a silica gel Sorbax column, using HPLC apparatus (Knawler). Samples of $100 \mu \mathrm{l}$ (approx. $2 \mathrm{mg}$ protein content) were loaded on the column and eluted with $0.2 \mathrm{M}$ sodium phosphate buffer, $\mathrm{pH} 7.0$, containing $0.1 \mathrm{M} \mathrm{Na}_{2} \mathrm{SO}_{4}$, at a flow rate of $1 \mathrm{ml} / \mathrm{min}$. The eluted material was recorded at 220, 260 and $280 \mathrm{~nm}$. To calculate the molecular weight of IEG-BAF the column was calibrated with gel-filtration molecular weight standards (Knawler and Bio-Rad).

\section{Cell cultures}

Mouse lymphoma cells L5178Y (wild type) were grown in Heraeus incubator at $37^{\circ} \mathrm{C}$ with $5 \% \mathrm{CO}_{2}$ humidified air, according to the procedure described by Venit and Perry [11]. The medium was RPMI1640 (Serva), supplemented with $10 \%$ bovine fetal serum (Sigma), penicillin 100 IU, streptomycin, $100 \mu \mathrm{g} / \mathrm{ml}$ (Pharmachim), and the following amino acids: L-arginine, $1.5 \mathrm{mM}$; L-asparagine, $0.24 \mathrm{mM}$; and L-glutamine, $1.5 \mathrm{mM}$ (all from Serva).

3T3 mouse fibroblasts were maintained in Dulbecco's modified Eagle's medium (DMEM), supplemented with $10 \%$ calf serum, 100 IU of peni- cillin and $100 \mu \mathrm{g} / \mathrm{ml}$ of streptomycin. The trypsin treatment was carried out as recommended in the Invittox Protocol [12], using trypsin purchased from Difco.

\section{Treatment of the cells with IEG}

Aliquots of $2 \mathrm{ml}$ of the mouse lymphoma L5178Y cell suspensions, grown to a density of approx. $3 \cdot 10^{4}$ cells/ml were treated with IEG at a final concentration of $1000,800,500,250$, and $100 \mu \mathrm{g} / \mathrm{ml}$, or with IEG-BAF at 250, 200, 150,100 and $50 \mu \mathrm{g} / \mathrm{ml}$. After $24 \mathrm{~h}$ Trypan blue (Serva) was added to final concentration of $0.5 \%$ to aliquots of the cultures for $5 \mathrm{~min}$ and the percentage of survived cells was determined. The total number of cells was counted in Burker's camera and the results were statistically processed using the Student's $t$-test.

3T3 mouse fibroblasts were grown in glass culture flasks (Flow Labs) with growth area of $75 \mathrm{~cm}^{2}$, until monolayers were formed and sufficient adhesion to the substrate occurred, after which they were trypsinized as described. The trypsinized cells were further grown in culture tubes (Leighton Flow Labs.) with previously placed cover slips $(9 \times 35 \mathrm{~mm}$, Chance Proper). After additional $24 \mathrm{~h}$ the medium was replaced with fresh aliquots containing IEG at a final concentration of $1000 \mu \mathrm{g} / \mathrm{ml}$ or $500 \mu \mathrm{g} / \mathrm{ml}$. The cells were vissualy inspected on inverted microscope (Karl-Zeiss) in $24 \mathrm{~h}$ intervals until monolayers were formed for changes in their shape, the level of adhesion, the density of the suspension and eventually damages caused by the treating agent. Untreated controls and treated cells were photographed directly in the medium or after they have been fixed with $5 \%$ methanol on the cover slips.

\section{Results and Discussion}

\section{Purification of IEG-BAF}

The typical chromatographic patern of IEG is presented on Fig. 1. When water was used as the eluent instead of phosphate buffer this resulted in an improved separation. The peak of the biological 


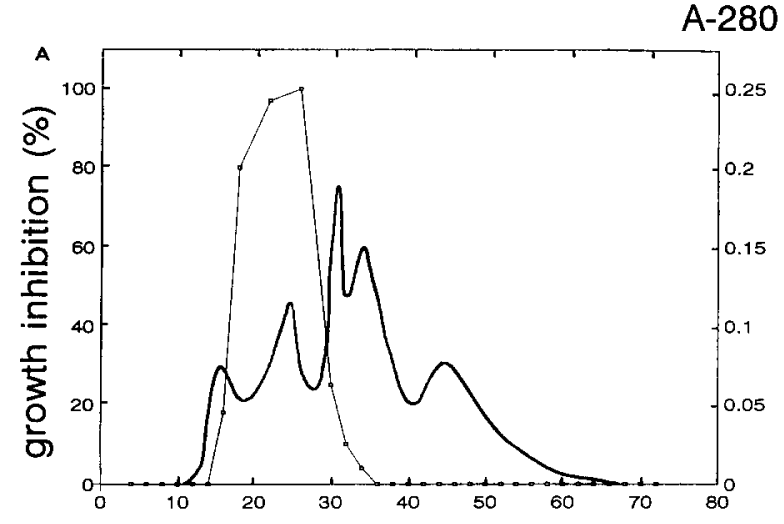

elution volume $(\mathrm{ml})$

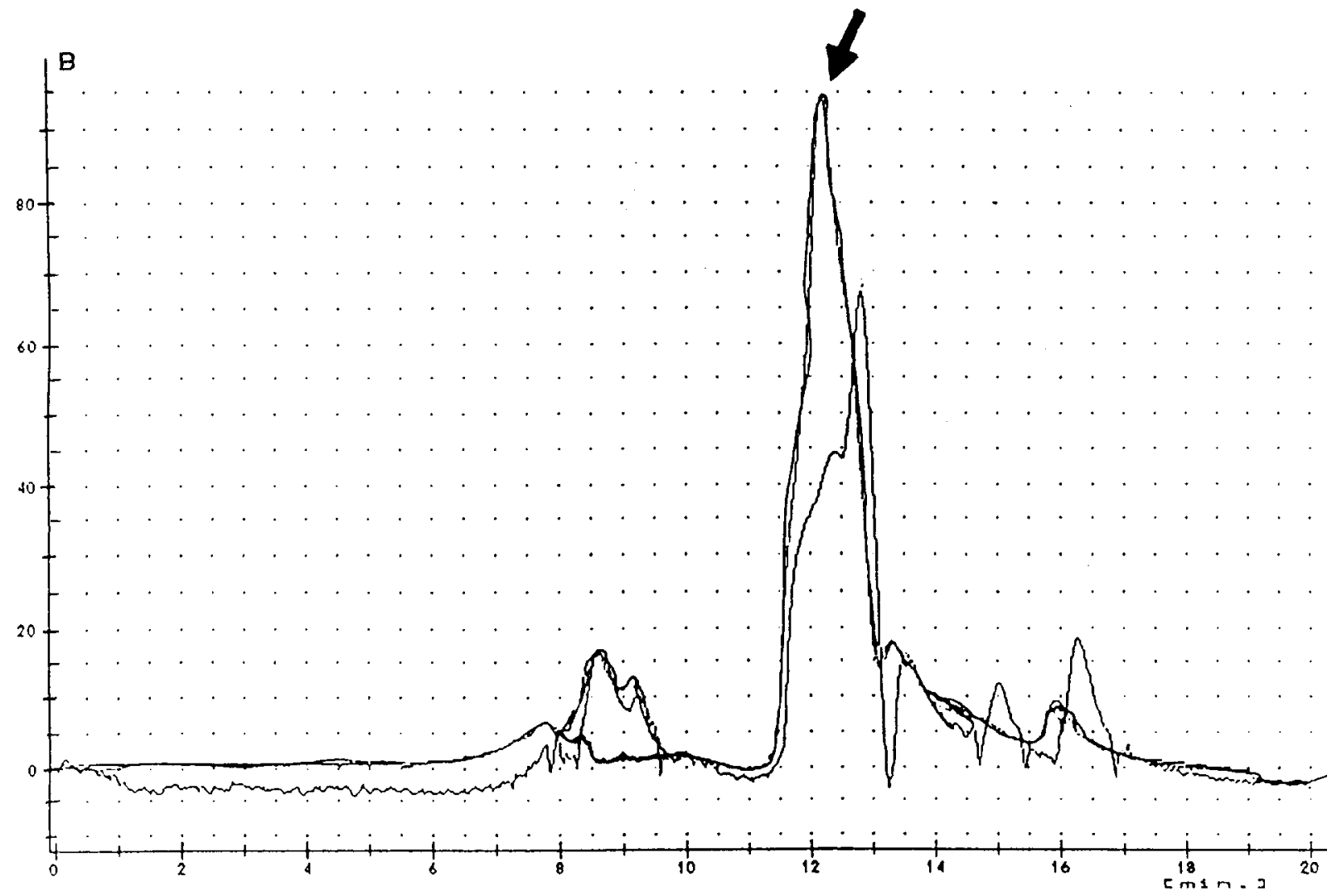

Fig. 1. (A) Purification of IEG by gel filtration on Sephadex G25. A sample of $8.5 \mathrm{mg}$ of IEG was run on a Sephadex G25 column $\left(1 \times 47 \mathrm{~cm}\right.$, I.D.) at a flow rate of $19 \mathrm{ml} / \mathrm{h} / \mathrm{cm}^{2}$. The elution was carried out with redistilled deionazed water and the eluate was monitored at $280 \mathrm{~nm}$. Fractions of $2 \mathrm{ml}$ were collected throughout. The activity of each fraction $\left(-{ }_{-}\right)$is expressed as percentage of growth inhibition caused on cultured L5178Y mouse lymphoma cells. The void volume of the column was $12 \mathrm{ml}$ and the elution positions of A and B chains of human insulin corresponded to $39 \mathrm{ml}$ and $28 \mathrm{ml}$, respectively (not shown). (B) HPLC of the purified IEG-BAF. An aliquot 
activity in both cases was obtained at $25 \mathrm{ml}$ when the analytical column was used, however the specific activity of the combined fractions was approx. $30 \%$ higher in the preparation with water as the eluent (not shown). Thus, we used water to elute the samples in all subsequent purification cycles. The purity of IEG-BAF was estimated by HPLC-chromatography. A peak of retention time of $12.25 \mathrm{~min}$ (see insert to Fig. 1) proved to be the major peptide in the sample, representing $89 \%$ of the total material which absorbs at 260 and $280 \mathrm{~nm}$, as based on computing the surface area of the peaks. It completely overlaped the peak of biological activity (data not shown). Thus, we conclude that our preparation of IEG-BAF is at least $80 \%$ pure.

IEG-BAF appeared at possition corresponding to approximately $4000 \mathrm{Da}$ when our analytical G-25 column was calibrated with $\mathrm{A}$ and $\mathrm{B}$ chains of human insulin and cytochrome $c$. This value is in good agreement with the one calculated using the HPLC Sorbax column, $4450 \pm 180$ Da (mean \pm S.D. of 6 independent runs of 2 different preparations).

\section{Spectral analysis of purifeid IEG-BAF}

The spectral scan of IEG-BAF preparation revealed two maxima at 206 and $265 \mathrm{~nm}$, respectively (not shown). A second derivative of the first maximum identified the presence of few additional components with a characteristic peak at $238 \mathrm{~nm}$. Based on this data we suggest that IEG-BAF is most likely a peptidyl-nucleotidate, although additional studies are needed to identify its exact chemical composition.

Effects of IEG on $3 T 3$ mouse fibroblasts and L5178Y mouse lymphoma cells

Figs. 2 and 3 present the effects of IEG on the cultured mouse $3 \mathrm{~T} 3$ fibroblasts at $24 \mathrm{~h}$ (Fig. 2) and
$72 \mathrm{~h}$ (Fig. 3) after addition of IEG, respectively. At $1000 \mu \mathrm{g} / \mathrm{ml}$ of IEG many of the cells were dead at 24 $\mathrm{h}$. The cells which have still been attached to the substrate became round-shaped and were easily removed upon agitation, whereas those which were tightly bound were flat and had long and thin extensions (Fig. 2a). The attached fibroblasts were separately distributed and only few of them were grouped in a network. Most of the cells were round-shaped and contained huge nuclei with 2 or 3 nucleoli. Dividing cells were not observed. At the lower concentration of IEG applied ( $500 \mu \mathrm{g} / \mathrm{ml}$, Fig. $2 \mathrm{~b})$, the cells adherent to the cover glass were bound tightly with their cytoplasmic projections forming a network. Most of the fibroblasts were round-shaped but also elongated cells were found. Again dividing cells were not observed. The control untreated fibroblasts (Fig. 2c) were lancet-shaped with long projections located on the poles of the longitudinal axis of the cell. In contrast with the treated cells many of the controls were in contact with each other by the means of not only the cytoplasmic projections but also with considerable part of their plasmalemmas.

In the cultures treated for $48 \mathrm{~h}$ dividing fibroblasts were not found in contrast with the controls in which most of the surface of the glass was already occupied by cells forming monolayer zones (not shown).

IEG at $1000 \mu \mathrm{g} / \mathrm{ml}$ prevented the formation of monolayers at $72 \mathrm{~h}$ of treatment (Fig. 3a). These cells were mostly single and randomly distributed. In cultures containing $500 \mu \mathrm{g} / \mathrm{ml}$ of IEG all the cells were included in a network formed by their cytoplasmic projections and completely covering the growth surface (Fig. 3b). In the control cultures monolayers were already formed and occupied the total surface of the cover slips (Fig. 3c).

When $1000 \mu \mathrm{g} / \mathrm{ml}$ of IEG was applied for $96 \mathrm{~h}$ the cells did not form monolayers. The cover slips were

of $100 \mu \mathrm{l}$ of the purified IEG-BAF was run on silica-gel Sorbax column at a flow rate of $1 \mathrm{ml} / \mathrm{min}$ as described in the text and absorbance recorded at 220 and $260 \mathrm{~nm}$. The pattern of the molecular weight standards recorded at 220 nm is shown on the same chromatogram. The position of IEG-BAF is indicated by an arrow. 

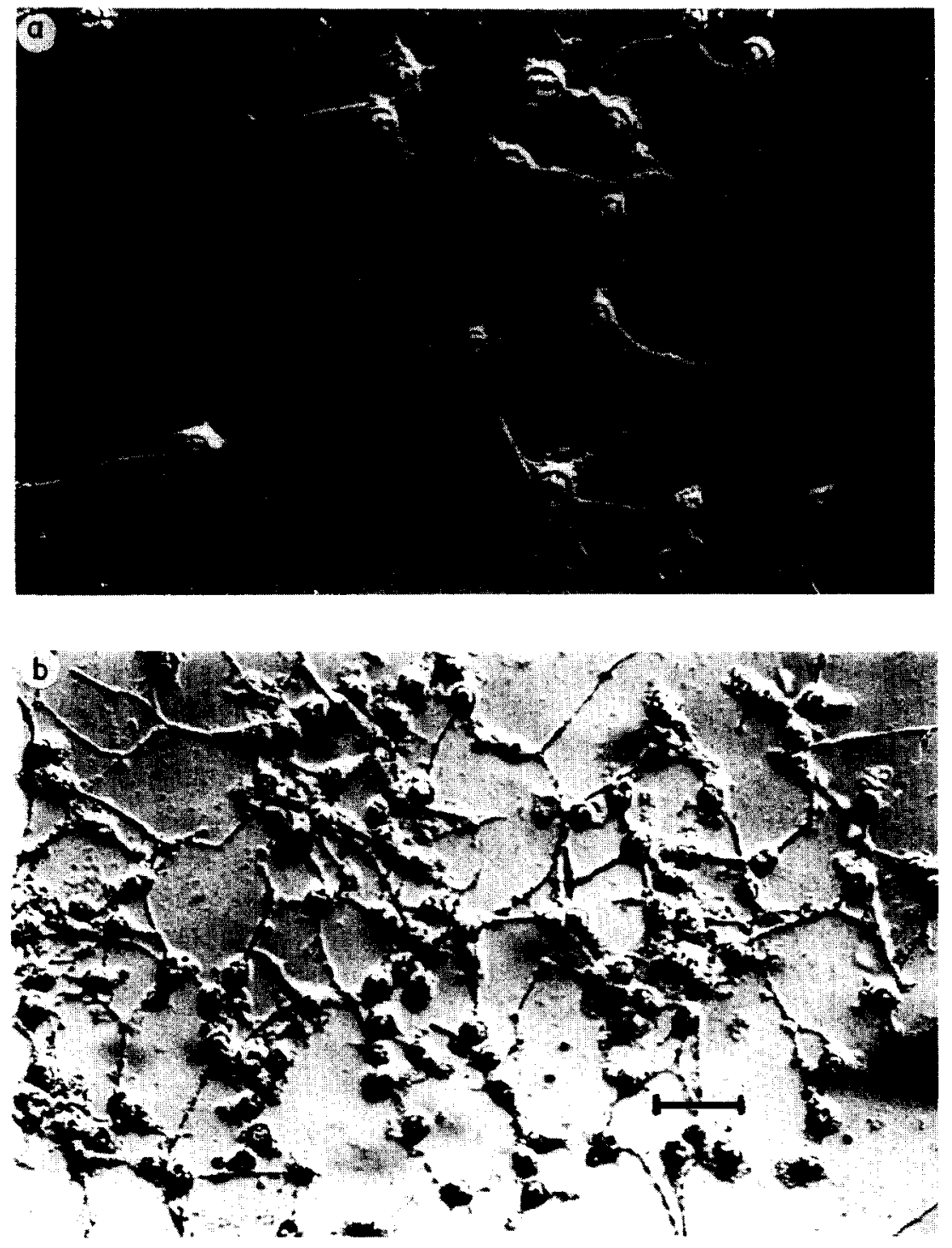

Fig. 2a, b.

covered by separate cells with only few grouped in clasters. At $500 \mu \mathrm{g} / \mathrm{ml}$ clearly observable monolayers were seen and considerable number of cells were dividing. Some of the cells were round-shaped and had long cytoplasmic projections. In the control cultures dividing fibroblasts were not found (not shown).

As can be seen on Figs. 2 and 3, considerable inhibition of the cell growth was observed in the presence of high amounts of IEG, especially in the early stages of growth ( $24 \mathrm{~h})$.

The present results of growth inhibitlon caused by IEG on cultured 3T3 mouse fibroblasts are in good agreement with our previous observations for the in vivo inhibition of the proliferation of small intestine epithelial cells $[4,5]$. In the present study IEG caused typical changes in the shape of the treated 


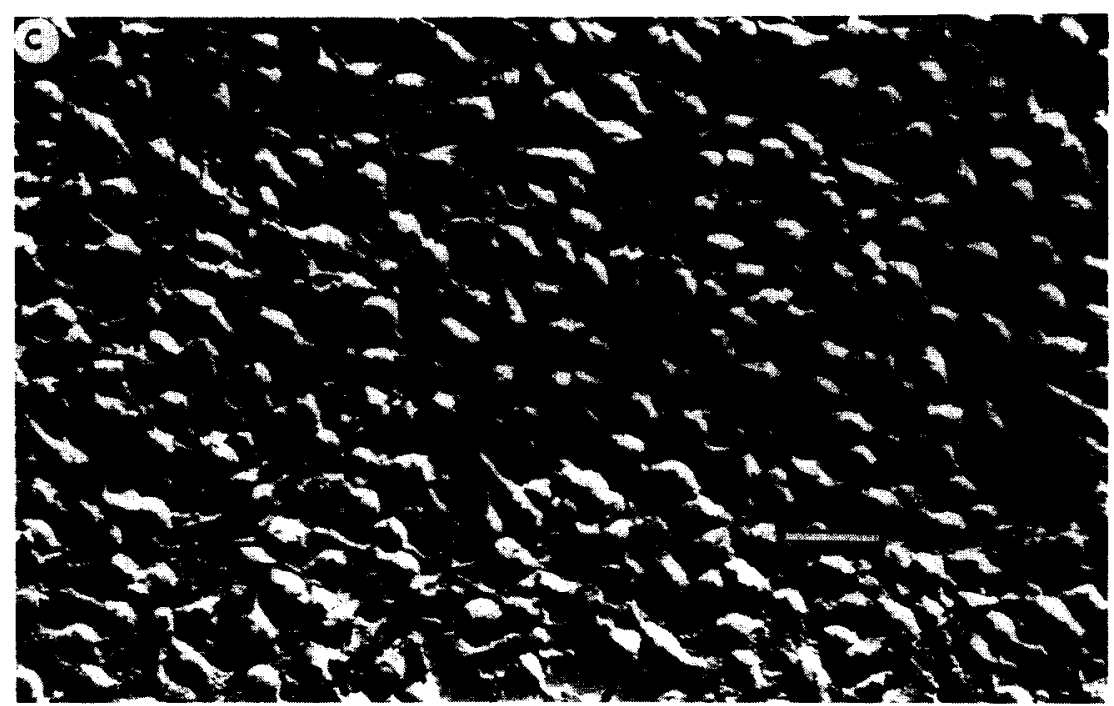

Fig. 2. Effects of IEG on 3T3 mouse fibroblasts, 24 h of treatment. 3 T3 mouse fibroblasts were grown in glass culture flasks until monolayers were formed and then trypsinized. The cells were subcultured for $24 \mathrm{~h}$ in tubes containing glass cover slips and the medium replaced with aliquots of fresh medium containing IEG at $1000 \mu \mathrm{g} / \mathrm{ml}$ (a), $500 \mu \mathrm{g} / \mathrm{ml}$ (b) or PBS (c) as a control. After additional $24 \mathrm{~h}$ the preparations were fixed with $5 \%$ methanol and microscoped using pseudorelief technique. Bar represents a scale of $100 \mu \mathrm{m}$.

fibroblasts, their orientation on the substrate and their ability to form monolayers. At the highest concentration of IEG applied $(1000 \mu \mathrm{g} / \mathrm{ml})$ a considerable reduction in the total number of cells was ob- served together with features characteristic for severe cell damages. Dividing cells were not found among the survived fibroblasts. The number of damaged cells was lower at $500 \mu \mathrm{g} / \mathrm{ml}$ of IEG but the growth

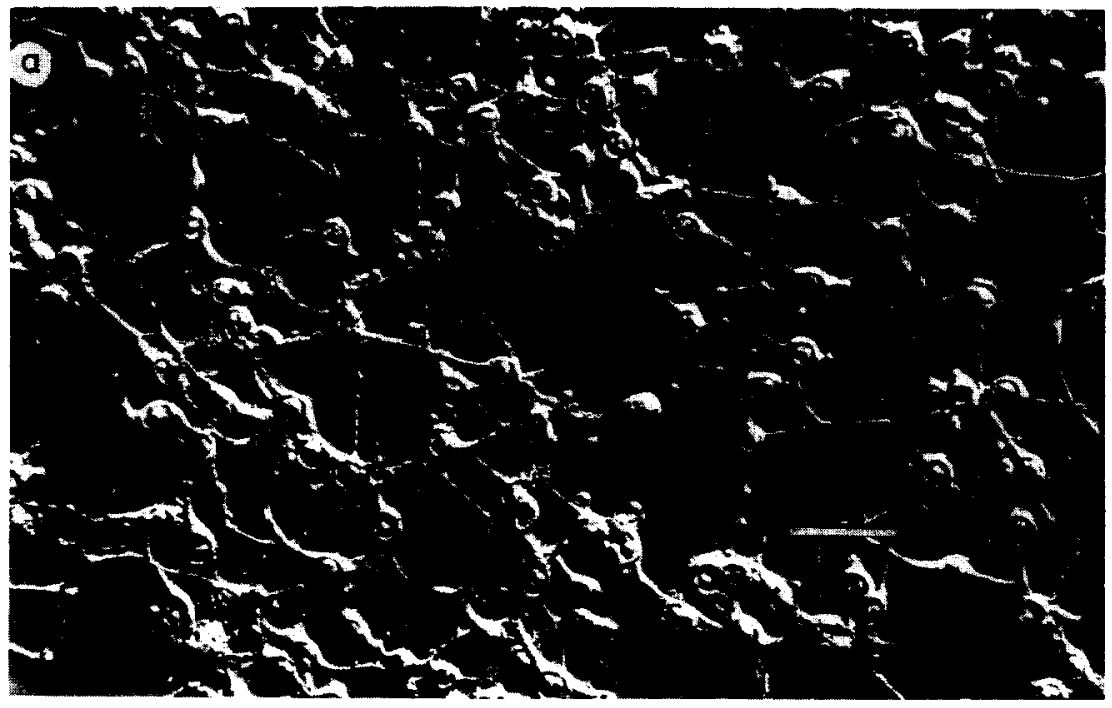

Fig. 3a. 

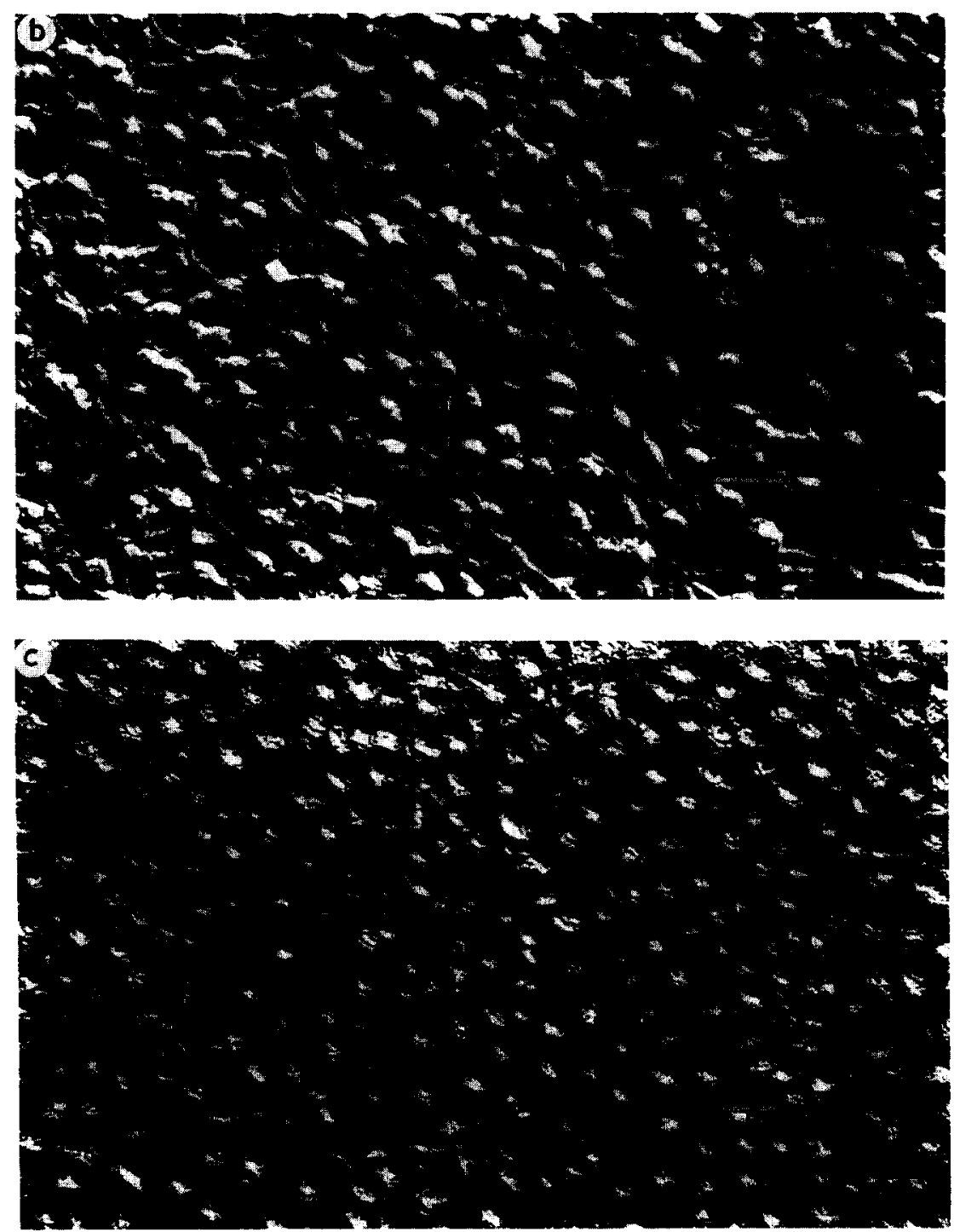

Fig. 3. Effects of IEG on 3 T3 mouse fibroblasts, $72 \mathrm{~h}$ of treatment. All conditions and designations are as described in the legend to Fig. 2, except that the cells were treated with IEG or PBS for $72 \mathrm{~h}$. Bar equals $100 \mu \mathrm{m}$.

inhibitiion was also clearly observed. These changes were especially indicative at up to $48 \mathrm{~h}$ of treatment. At the later stages of treatment $(72 \mathrm{~h}$ and $96 \mathrm{~h}$ ) the number of fibroblasts on the cover slips increased and also mitotic cells were observed, which suggests that the cultured cells have overcome the inhibitory effect of the agent when treated with relatively low amounts of IEG.
Table I presents the growth inhibition in percentage caused by IEG and IEG-BAF on L5178Y mouse lymphoma cells at $24 \mathrm{~h}$. At $1000 \mu \mathrm{g} / \mathrm{ml}$ of IEG and $250 \mu \mathrm{g} / \mathrm{ml}$ of IEG-BAF the average growth inhibition was $83 \%$ and $79.6 \%$, respectively, as compared to the control untreated cultures. There was no observable effect on the cell growth at concentrations of IEG and IEG-BAF of $100 \mu \mathrm{g} / \mathrm{ml}$ and $50 \mu \mathrm{g} / \mathrm{ml}$, re- 


\section{TABLE I}

Growth inhibition of mouse lymphoma L5178Y cells by IEG and purified IEG-BAF. Aliquots of $2 \mathrm{ml}$ of mouse lymphoma L5178Y cell suspensions, grown to a density of $3 \cdot 10^{4}$ cells $/ \mathrm{ml}$ were treated with IEG or IEG-BAF at the indicated concentrations for $24 \mathrm{~h}$. Cells were counted in Burker's camera and the growth inhibition was calculated in percentage of controls treated with sterile PBS. The results are the means \pm S.D., $(n=12)$.

\begin{tabular}{|c|c|c|c|c|c|}
\hline \multicolumn{3}{|l|}{ IEG } & \multicolumn{3}{|c|}{ IEG-BAF } \\
\hline $\begin{array}{l}\text { [Agent] } \\
\mu \mathrm{g} / \mathrm{ml}\end{array}$ & $\begin{array}{l}\text { cells } \\
/ \mathrm{ml} \cdot 10^{4}\end{array}$ & $\begin{array}{l}\text { Inhibi- } \\
\text { tion } \\
\left(\begin{array}{l}0 \\
\text { o }\end{array}\right)\end{array}$ & $\begin{array}{l}\text { [Agent] } \\
\mu \mathrm{g} / \mathrm{ml}\end{array}$ & $\begin{array}{l}\text { cells } \\
/ \mathrm{ml} \cdot 10^{4}\end{array}$ & $\begin{array}{l}\text { Inhibi- } \\
\text { tion } \\
\left(\begin{array}{c}0 \\
0\end{array}\right)\end{array}$ \\
\hline 1000 & $10.3 \pm 1.1^{* * *}$ & 83.0 & 250 & $12.5 \pm 0.9^{* * *}$ & 79.6 \\
\hline 800 & $27.5 \pm 1.4^{* *}$ & 55.0 & 200 & $25.5 \pm 2.2^{*}$ & 54.2 \\
\hline 500 & $50.0 \pm 1.5^{*}$ & 18.0 & 150 & $41.8 \pm 1.6^{*}$ & 25.0 \\
\hline 250 & $53.0 \pm 2.0^{*}$ & 13.0 & 100 & $53.7 \pm 1.4^{*}$ & 0.6 \\
\hline 100 & $61.6 \pm 0.8$ & 0.0 & 50 & $56.3 \pm 1.4$ & 0.0 \\
\hline 0 & $61.0 \pm 1.4$ & & 0 & $55.7 \pm 1.0$ & \\
\hline
\end{tabular}

${ }^{*}=P<0.05,{ }^{* *}=P<0.01, * * *=P<0.001$, statistically different from 1 compared to the control values.

spectively. The corresponding concentrations of IEG and IEG-BAF inhibiting the growth of L5178Y lymphoma cells by $50 \%$ ( $\mathrm{IC}_{50}$ values) were calculated to be 759.5 and $192.8 \mu \mathrm{g} / \mathrm{ml}$, respectively.

In addition to the above described, we also studied the effects of IEG-BAF on mouse myeloma $S p 2$, Ag8 and METH-A cell lines. Our preliminary results indicated a high sensitivity of these cells to microgram quantities of the purified peptide. The average growth inhibition was $70 \pm 9 \%$ at the same concentrations of IEG-BAF applied as in the experiments presented in Table I.

From our data it is hard to assess what is the physiological significance of IEG since hundreds of micrograms were required for its biological activity. However, the in vitro experimental conditions we used in this study may not be optimal for this activity. As pointed out by Skraastad and coworkers [2] the effect of their colon mitosis inhibitor was antagonized by insulin or serum factors in the culture medium. Finally, IEG might operate through a low affinity and/or high capacity receptor. Future investigations will address a more detailed characteriza- tion of the growth inhibition caused by IEG-BAF as well as the signal transduction mechanisms involved in the observed effects.

\section{References}

1 Go, V.L.W., Owyand, C., Radioimmunoassay of gastrointestinal hormones. In G.Glass (Ed.), Progress in Gastroenterology, Creme and Straton, New York, 1987, pp. 153-163.

2 Skaastad, O., Reichelt, K.L., An endogenous colon mitosis inhibitor reduces proliferation of colon carcinoma cells (HT29) in serum restricted medium, Virchows Arch. B, 56 (1989) 393396.

3 Skaastad, O., Reichelt, K.L., An endogenous colon mitosis inhibitor and dietary calcium inhibit the increased colonic cell proliferation induced by cholic acid, Scand. J. Gastroent., 23 (1988) 801-807.

4 Rousev, G., Trofonov, B., and Bochev, N., A method for the isolation of substances with morphogenic activity, Invention at INRA, Sofia, No. 37396, MPK-A61K35/38, 1986, pp.,1-6 (in Bulgarian).

5 Trifonov, B., Gabrovska, L., Rousev, G., Bochev, N., Isolation and action of enterocytogenins, F.E.C.S., Fifth International Conference on Chemistry and Biotechnology of Biologically Active Natural Products., Bulg. Acad. Sci Inst. of Org. Chem., Conference Proceedings, Jusautor, Sofia, Vol. 3, 1989, pp. 423-426.

6 Trifonov, B., Rousev, G., Bochev, N. and Tjanev, G., A method for isolation of a biostimulating substance., Patent BG No. 49927 MPK, A61K37/02, INRA, Sofia, 1992, pp. 1-3 (in Bulgarian).

7 Trifonov, B., Kristev, A., Zaprjanov, G., Lucanov, J. and Kostadinova, 1., Effects of a novel intestinal peptide (enterogenin) on the contractile and bioelectric activity of intestinal smooth muscle from rat and guinea pig, J. Gastrointest. Motil., 4 (1992) 193-199.

8 Trifonov, B., Lucanov, J. and Mileva, E., Effect of two biologically active substances isolated from enterocytes on the motility of the smooth muscle of gastrointestinal tract. Abstracts of the Third Europian Symposium on Gastrointestinal Motility, Belfry Halls, Markt, Brugeses Belgium, June 19-21, 1986 , p. 45.

9 Lowry, O.H., Rosenbrough, N.J., Farr, A.L., Randall, R.J., Protein measurement with the Folin phenol reagent, J. Biol. Chem., 193 (1951) 265-275.

10 Bailey, L.J., Techniques in protein chemistry, Elsevier, Amsrterdam, 1967, pp. 343-346.

11 Arlett, C.F. and Cole, J., Detection of Mutations in cultured mammalian cells. In S. Venitt and J.M. Perry (Eds.), Mutagenicity lesting, IRL Press, Oxford, 1984, pp. 249-268.

12 Invittox, The Ergatt/Frame Data Bank of in vitro techniques in toxicology, Protocol \#46, 1992, p. 10. 